DOI https://doi.org/10.36059/978-966-397-118-6/245-263

\title{
PROFESSIONAL OBSERVATION SKILLS OF SPECIAL EDUCATION TEACHERS
}

\section{Tsybuliak N. Yu.}

\section{INTRODUCTION}

One of the challenges for the modern society is the incessant positive dynamics of the number of children with special educational needs. State policy, regulatory changes make sure steps for resolving this extremely important, but at the same time, complicated and controversial problem. Therefore, in the context of developing a modern special education in Ukraine, the profession of a special teacher working with children with physical, mental, intellectual development and sensory impairments becomes relevant. Its main mission is providing of qualified assistance to children with special educational needs in specialized educational institutions or in inclusive schools of general secondary education.

The latter involves mastering necessary knowledge, abilities and skills, as well as development of a number of professionally important qualities. Observation skills are particularly important among the latter; being the basis for cognition and the understanding of child's individual uniqueness, they guarantee humanization and individualization of the educational process, efficiency and progress of pedagogical activity. The lack of professional supervision of a special teacher leads to the depersonalization of the individual psychological content of the child's person with special educational needs.

Review of psycho-pedagogical literature shows interest in the issues of observation skills and diversity of approaches to understanding the essence of this concept. It is considered as an ability (S. Holovin, H. Kostiuk), personal quality (S. Maksymenko, D. Nikolenko et al.), personality trait (M. Hamezo, O. Petrova, et al.), a component of socioperceptual competence of a specialist (V. Zazykin, I. Kulkova, et al.). The researchers' attention is focused on works, where observation skills are defined as a professionally important quality of representatives of different jobs: public employees (Yu. Tereshchenko, D. Nikolenko, et al.), lawyers (I. Abakumova, O. Stoliarenko, et al.), psychologists (L. Rehush, V. Kovalov, V. Kuzmenko, et al.), teachers (H. Kyslova, 
L. Kolodina, V. Lezhnina, T. Mandrykina, O. Telieieva, et al.). In particular, when studying future teachers' observation skills, the following aspects have been revealed: psychological peculiarities of their formation (H. Kyslova), impact of observation skills on the effectiveness of pedagogical interaction (L. Kolodina), interrelation between their demonstration and accuracy of empirical predication (V. Lezhnina), pedagogical features of forming observation skills in communication process (T. Mandrykina), effectiveness of using training exercises for their development (O. Telieieva).

Despite a great number of research works devoted to this issue, there is the lack of fundamental works concerning the development of observation skills in special education teachers. Studying this issue will make it possible to adjust differences between contemporary requirements to observation skills demonstration and theoretical justification, as well as actual practice of their development in the process of training future special education teachers; the need for methodical support of these skills development and insufficient working out of corresponding recommendations and methodological support.

The aim of the paper is theoretical and experimental determination and characterization of the psychological features of demonstrating professional observation skills by future special education teachers.

\section{Research methods}

To attain the aim of the paper and complete the formulated tasks, we have developed a research programme, which involved the use of the following methods:

- theoretical (analysis, synthesis, the summarizing of scientific literature on the problem of the research);

- empirical (observation, questioning, testing, namely: "Correction task" (B. Burdon, modified by V. Anfimov), "Evaluation of perception capacity", "Elimination method", "Complicated analogy", "Comparison of notions", "Distinguishing essential features" (A. Malenov), "Memory for images" and "Long-term memory" (L. Stoliarenko), "Socio-perceptual observation skills" (M. Kiloshenko), "Expression groups" (J. Gilford and M. Sullivan, modified by O. Mykhailova), "Diagnostics of the level of development of abilities for proper interpretation of nonverbal behaviour" (V. Labunska), "Significance of observation skills for preschool teachers" work";

- statistical (comparative and correlation analysis); 
obtained).

- interpretative (analysis, synthesis, systematization of the data

The research was conducted at Berdyansk State Pedagogical University. 59 third- and fourth-year students majoring in special education programme became participants of the research.

\section{The essence of professional observation of a special teacher}

Before we reveal the essence of professional observation of future teachers of preschool education, let's consider the essence of the concept of "observation" as a mental phenomenon. In scientific works observation is considered from different positions: as a personality quality (V. Davydov, B. Lomov, D. Nikolenko, et al.), its rice (M. Gamezo, L. Orlova, O. Petrova, et al.), ability (Yu. Gilbukh, S. Golovin, G. Kostyuk, M. Yaroshevsky, et al.), a component of the social-perceptual competence of a professional (I. Wegerchuk, V. Zazykin, I. Kulkova, et al.). A different basis of observation is also determined. Most scholars (B. Lomov, S. Maksimenko, B. Teplov, et al.) believe that its basis is perception. According to M. Savchin, observation is also associated with the peculiarities of distribution, amount and refocusing of attention ${ }^{1}$. In the writings of L. Zankov, the concept under investigation is defined as the ability to observe ${ }^{2}$. Some scholars (S. Golovin, A. Petrovsky, M. Yaroshevsky, et al.) associate observation with the development of empathy, reflection or the peculiarity of personality guidance.

The ambiguity of approaches to the study of the concept of "observation" affects its interpretation. The use of this concept for scientific and practical purposes requires careful theoretical analysis and refinement of its content. Famous psychologist B. Ananiev believed that observational - is the property of sensory organization of personality, which is based on the processes of sensation and perception. They allow distinguishing of signs and objects that have minor differences, fixing them at a minimum perception of time ${ }^{3}$. L. Regusch adheres to the same

${ }^{1}$ Савчин М. В. Педагогічна психологія : навчальний посібник. К. : Академвидав, 2007. Ст. 344.

2 Занков Л. В. Наглядность и активизация учащихся в обучении. М. : Учпедгиз, 1960. Ст. 144.

${ }^{3}$ Ананьев Б. Г. Воспитание наблюдательности школьников. Л. : Лениздат, 1940. Ст. 6. 
idea of the interpretation of the concept under study ${ }^{4}$. In the paper of T. Mandrykina, in addition to perception, the role of attention, memory, thinking, imagination is emphasized. The scientist notes that observation is the interaction of cognitive mental processes in unity with the emotional and volitional processes of personality ${ }^{5}$. I. Bila believes that observation is a purposeful perception, a unity of attention and thinking, a memory, a complex cognitive process in which the unity of sensual and rational cognition manifests itself ${ }^{6}$.

In the study of G. Kislova is noted that in the system "human human" observation should be considered not only as a property of sensory organization of personality, but also as the ability to social perception $^{7}$. The same opinion is observed by L. Kolodina. She understands observation as the ability of a person to perceive and assess the basic parameters of interpersonal relationships adequately. In this case, adequacy implies the ability to make correct judgments about other people $^{8}$. As A. Markova points out, observation is the ability to read a man as a book in expressive movements ${ }^{9}$. According to I. Bekh, observation is the ability to capture obscure but psychologically significant details in the behavior of a particular pupil ${ }^{10}$. There is another rather widespread point of view: observation - is a stable quality of personality, which is based on observation ${ }^{11}$.

${ }^{4}$ Регуш Л. А. Практикум по наблюдению и наблюдательности. СПб. : ПИТЕР, 2008. СТ. 12.

5 Мандрыкина Т. С. Формирование педагогической наблюдательности будущего учителя в процессе общения : автореф. дис. на соиск. науч. степени канд. пед. наук : спец. 13.00.01 «Общая педагогика, история педагогики и образования». К., 1987. Ст. 5. № 4. Ст. 9.

6 Біла I. Спостережливість - ключ до пізнання. Дошкільне виховання. 2008.

7 Кислова Г. И. Развитие наблюдательности в процессе профессиональной подготовки будущих учителей : дис. ... канд. психол. наук : спец. 19.00.07 «Педагогическая психология». Рос. гос. пед. ун-т им. А. И. Герцена. СПб., 1995. Ст. 12.

8 Колодина Л. В. Наблюдательность личности как фактор формирования педагогического взаимодействия в системе «Учитель-Ученик» : дис. ... канд. психол. наук : спец. 19.00.01 «Общая психология, история психологии». Новосибирск, 2000. СТ. 59.

${ }^{9}$ Маркова А. К. Психология труда учителя : кн. для учителя. М. : Просвещение, 1994. Ст. 24.

${ }^{10}$ Бех І. Д. Виховання особистості : підручник. К. : Либідь, 2008. Ст. 44.

11 Ковалев В. В. Развитие наблюдательности студентов-психологов в процессе изучения дисциплин анатомо-физиологического цикла : дис. ... канд. психол. наук : спец. 19.00.13 «Психология развития, акмеология». М., 2010. Ст. 17. 
An analysis of different views on the interpretation of the nature of observation has shown that almost all scholars attach importance to the mental processes that, in their opinion, form the basis of observation: sensation, perception, thinking, attention, memory. This is confirmed in the studies of I. Pavlov and I. Sechenov. They found that observation is a derivative of the reflex activity of the brain, which is based on irritability as the ability of living matter to respond to external stimuli and sensitivity to them. This ability manifests itself in varying degrees of susceptibility. The level of plasticity of the cortex of the cerebral hemispheres and the strength of the stimulus determine the qualitative level of observation. Physiologists emphasize that this personality quality develops under the influence of maturation of the central nervous system, education and life experience.

According to D. Nikolenko, the primary in the act of observation and observation is the ability of the central nervous system to excite under the action of the needs of the organism, which directs the analyzers on the relevant objects, environmental phenomena that can meet this need. It has an arbitrary character, which depends on the nervous excitement, images, traces of memory, thoughts that arise in the cortex of the cerebral hemispheres. In view of this observation is impossible without specific psychophysiological activity, aimed at the knowledge of reality ${ }^{12}$.

In the scientific literature, along with the concept of "observation", the concept of "monitoring" is used. For our study, it is important to establish a relationship between them. In pedagogical activity, monitoring is seen as mastering the system of mental and practical actions aimed at the perception of professionally important information for solving pedagogical problems and situations. N. Kuzmina notes that this process is based on previously acquired knowledge and skills, therefore, it is complex and comprehensive ${ }^{13}$. That is, monitoring is a planned, systematic, time-limited activity. Monitoring as a method of cognition of a person, provided multiple reigns and exercises goes into a stable quality of personality - observation. According to B. Ananiev,

12 Ніколенко Д. О. Психологічні особливості спостережливості в процесі випереджального відображення дійсності. Юридична психологія і педагогіка : наук. журнал. К. : Національна академія внутр. справ, 2014. 1 (15). Ст. 25.

${ }^{13}$ Кузьмина Н. В., Реан А. А. Профессионализм педагогической деятельности : методическое пособие. СПб. : Рыбинск : [Б. и.], 1993. Ст. 32. 
these concepts reflect the relationship between mental processes and personality properties ${ }^{14}$.

However, L. Zankova's study emphasizes that observation is a broader notion in its content than monitoring. The scientist defines the latter as one of the types of mental activity, which presupposes the presence of a task, purposefulness, planonomy of perception, comprehension of the object of perception ${ }^{15}$. At the same time, observation is a combination of certain personality traits, such as: the ability to observe, analyze an object, detect its properties in accordance with the goal, and also transfer the ability to observe, which is produced on some objects, on other, new ones.

This opinion is shared by $\mathrm{D}$. Nikolenko, noting that observation as a result of the observation process and an integrative cognitive perception provides:

1) the adequacy of the qualitative characteristics of the mental image of the quality of objects, phenomena and processes that are reflected in their integrity;

2) semantic hierarchy of reflection;

3) the combination attribute of reflection;

4) the creative mobility of reflection;

5) operational control of reflection and its result ${ }^{16}$.

Observation differs both from the process and from the monitoring method. Observation as a process involves the perception of objects in a particular program: where to look, what to listen to, what objects and their manifestations should be noticed, what and where to note, etc. It organizes the perception of a person, who, regardless of observation, can successfully observe even unusual and uninteresting objects for her. If we consider monitoring as a method, then this is a system of scientific means, algorithms and orders, through which it becomes possible to achieve the goal of psychological and pedagogical research. Unlike monitoring observation as a personality's quality involves a stable

14 Ананьев Б. Г. Воспитание наблюдательности школьников. Л. : Лениздат, 1940. Ст. 12.

Занков Л. В. Наглядность и активизация учащихся в обучении. М. : Учпедгиз, 1960. Ст. 34.

16 Ніколенко Д. О. Психологічні особливості спостережливості в процесі випереджального відображення дійсності. Юридична психологія і педагогіка : наук. журнал. К. : Національна академія внутр. справ, 2014. № 1 (15). Ст. 25. 
cognitive attitude to certain objects or phenomena that organizes the work of all mental functions of man. This quality acts as an integral phenomenon, which ensures the adequacy of the process of cognition, which manifests itself in the qualitative, quantitative and structural characteristics of the subjective reflection of objective reality. According to O. Bodal'ov, this allows to deeply and accurately understand the main features of the inner world of another person, to successfully evaluate it as a personality, as a subject of activity and very close to the reality of substituting it for individual peculiarity ${ }^{17}$.

Consequently, a stable cognitive attitude towards the environment and the acquisition of practical experience in monitoring predetermine the development of observation as a personal quality. If a special teacher shows a professional-cognitive attitude to the subjects of the educational process of the institution of education, this quality is transformed from a personal to a professionally important.

Taking into consideration the specific character of special education teacher's work, observation skills should be considered as a professionally important quality, which involves fixation and interpretation of significant, typical and even barely noticeable, but important for understanding individual features of educational process participants (children with special educational needs, parents, colleagues). Under the educational process participants we mean, first of all, children with special educational needs: observation skills are oriented at creating favourable conditions for children's mental development, keeping their individualities, caring for the development of their individual abilities, etc. Interaction between teachers and families is of great importance for coping with these tasks. Apart from children and parents, special educators must understand peculiarities of adults who have influence on child personality's development. In particular, the ability to determine and consider colleagues' emotional states determines the unity of requirements imposed on children as well as psychological climate, where children and teachers spend their day.

The disclosure of the essence of professional observation of a special teacher also implies the definition of its significance for the activity. We believe that observation is subordinated and aimed at the

17 Бодалев А. А. Восприятие и понимание человека человеком : монография. М. : Изд-во Моск. ун-та, 1982. Ст. 19. 
successful and effective implementation of professional activities and creative self-realization of the teacher. It becomes possible by creating a detailed, complete and holistic image of a child with special educational needs, taking into account her individual characteristics, understanding her relationships with peers, parents and adults. A supervised special teacher is able to timely and clearly diagnose a long and stable mental reality and to penetrate into the essence of the general situation of the existence of a child with special educational needs, to find an explanation, the reason for her behavior, and so on.

Let's highlight the importance of professional observation for pedagogical activity:

1) providing the possibility to organize and carry out educational work taking into account the needs and abilities of the child;

2) cognition and understanding of the child's inner world, its features of character and habits, inclinations and abilities, needs and interests, feelings and experiences, which are the basis for revealing the tendencies of development of a child with special educational needs and forecasting of individual variants of the formation of his personality;

3) providing the ability to understand the causes of the child's behavior, his goals, thoughts, intentions in certain situations of life, separating the essential from the incidental, important from the secondary, revealing links between these psychological symptoms;

4) creation of the basis for the construction and implementation of a personally oriented and individually differentiated educational process, determination of the effectiveness of methods and techniques, the creation of a developing environment, the introduction of situational and strategic changes in pedagogical activities to enhance the internal resources of a child with special educational needs;

5) identification of peculiarities of development of the children's collective (the relation of other children to a child with special educational needs, his social status, interaction between children, their interrelationships, etc.);

6) definition of the existing model of family relationships, the style of family education, the formation of a child's attachment to parents, attitude towards them, etc.;

7) determination of the effectiveness of influencing the methods and methods of working with parents and giving them the opportunity to 
feel understanding, interest and assistance, which serves as the foundation for building effective cooperation with the family;

8) creation of preconditions for the search by the special teacher of the individual creative way of self-realization in professional activity.

The list of tasks, the solution of which depends on the peculiarities of the professional observation of a specialist teacher, can be continued, but we believe that the main vectors of its importance for pedagogical activity have been introduced: the development of the personality of the child with special educational needs, cooperation with the family and professional self-development and self-realization.

In accordance with such an approach, peculiarities of demonstrating professional observation skills by special education teacher affect the success and effectiveness of performing the following functions:

- research - collection, analysis, systematization and classification of important information concerning individually psychological peculiarities of children with special educational needs (temperament types, psycho-emotional state, self-esteem, personal qualities, preferences, interests, etc.);

- organisational - most appropriate organization of various types of children's activities, taking their individual features into account;

- motivative - creating and providing favourable conditions for child's development (mental, physical, social, etc.), which requires teachers' continuous self-improvement;

- prognostic - predicting results and consequences of one's professional activities;

- controlling - studying children in the context of educational work with them, i.e. specifying personal characteristics of their development in close relation with the organizing and providing of teaching process, particularly the reasons that impede achievement of the desired level of personal qualities and traits development, and factors that contribute to successful achievement of goals, etc.;

- regulatory (or correctional) - quick revealing of differences between the tasks of preschool education and the state of their overcoming, which provides the most appropriate changing of a situation.

Consequently, professional observation skills of special education teacher are the basis for understanding individuality and uniqueness of each child with special educational needs. Their significance proves the 
need for its purposeful development. Therefore, it is important to find out existing peculiarities of demonstrating professional observation skills by future special education teachers. This task implies revealing the inner structure of this quality.

On the basis of theoretical analysis of research works devoted to the issues of professional observation skills (L. Rehush, H. Kyslova, V. Kovalov, D. Nikolenko, M. Sherin, et al.) the structure of this quality and criteria for its studying have been specified:

- the motivational and target-oriented component (criterion incentives and goals of their demonstration);

- the cognitive component (criterion - maturity of cognitive mental processes that form the basis for observation skills);

- the operational component (criterion - maturity of necessary and adequate actions related to the determining, differentiation, comparison and adequate interpretation of demonstrations of children's individual uniqueness).

These components ensure the fixation and interpretation of the essential, characteristic and even imperfect external manifestations of the individual characteristics of the educational process subjects of the educational institution, which is important for their cognition and understanding. The complex of these components determines the purposeful professional-cognitive activity, in which the organically combined sensory and rational reflection of the pedagogical process.

Thus, professional observation is a professionally important quality of special teacher. Its essence consists in fixing and interpreting the essential, characteristic and even imperfect external manifestations of the individual characteristics of children with special educational needs, their parents and colleagues. This quality is the basis of cognition and understanding of the inner world of a child with special educational needs, defines the success, efficiency and productivity of teaching activity and the possibility of creative self-realization. Professional observation has a multi-component structure, which includes motivational-target, cognitive and operational components.

\section{The psychological features of professional observation skills of future special education teachers}

The empirical study of psychological peculiarities of demonstrations of special education teachers' professional observation 
skills was based on the above-mentioned structure. Below are the characteristics of the empirical data obtained.

According to the criterion "incentives and goals of their demonstration", we have found that $7.27 \%$ of future special education teachers had the high level of its development, $53.42 \%$ had the adequate level, $29.06 \%$ - the critical level, $10.25 \%$ - the unacceptable level. The results obtained make it possible to state that the majority of students under study are characterized by domination of professional motives and goals of demonstrating observation skills, sufficient maturity of focus on studying and understanding personal characteristics of the participants of the educational process of an educational institution. They express stable professional interest in fixation and interpretation of external demonstrations of personal characteristics of a child with special educational needs (their parents and teachers in particular). The abovementioned feature of professional observation skills demonstrates students' sufficient motivation and focus on their actualization for studying and understanding children's personal characteristics and their special educational needs.

The results obtained according to the criterion "maturity of cognitive mental processes that form the basis for observation skills" show that $3.42 \%$ of future special education teachers are characterized by the high level of its development, $48.29 \%$ - by the adequate level, $40.17 \%$ - the critical level, and $8.12 \%$ - by the unacceptable one. Consequently, the majority of the students under study are characterized by sufficient indicators of the capacity of perception and perceptivity; concentration, stability and distribution of attention; image and longterm memory; analysis, synthesis, comparison, abstraction, and generalization. These features indicate potential opportunity of observation skills demonstration by future special education teachers in their work.

The criterion "maturity of necessary and adequate actions concerning determining, differentiation, comparison and adequate interpretation of demonstrations of children's individual uniqueness" is developed at the high level in $8.97 \%$ of the surveyed, at the adequate level - in $12.65 \%$, at the critical one - in $60.85 \%$, and at the unacceptable level - in $17.53 \%$. These results make it possible to state that the majority of the students are able to determine significant and typical external demonstrations of personal characteristics of an 
individual. However, they make a great number of mistakes when comparing, differentiating, and explaining them. For this reason, it will be difficult for them to identify children's personal characteristics and special educational needs. So as a result it can be negatively impact to the recognizing, accepting and understanding of a child.

Comparative analysis of the indicators of structural components of future preschool teachers' observation skills according to the specified criteria enables us to state that the highest indicators were found when studying the cognitive component and the lowest - the operational one. The empirical data indicate that the students are able to activate cognitive mental processes that are the basis for professional observation skills at the sufficient level. Also the future special education teachers are motivated enough to take careful observation to understand the individual characteristics of children with special educational needs. However, they have many problems with fixation and adequate interpretation of significant, typical, and especially barely visible external demonstrations of personal characteristics of the participants of the educational process.

If we are compared the psychological peculiarities of the future special education teachers with the psychological peculiarities of the future preschool teachers, we find two significant differences ${ }^{18}$. The first one is that the future special education teachers are much more motivated to learn and understand a child with special educational needs; their motives are internal and professional, they are more sustainable. At the same time, for the preschool teachers are characterized by domination of extrinsic motives and formal goals of demonstrating observation skills, insufficient maturity of focus on studying and understanding personal characteristics of the participants of the educational process of a preschool educational institution. The students do not express stable professional interest in fixation and interpretation of external demonstrations of personal characteristics of a child (parents and teachers in particular).

The next main difference we obtain in the criterion "maturity of necessary and adequate actions concerning determining, differentiation,

18 Цибуляк Н. Психологічні особливості прояву спостережливості майбутніх вихователів дошкільних навчальних закладів. Педагогіка і психологія професійної освіти. 2013. № 4. Ст. 198. 
comparison and adequate interpretation of demonstrations of children's individual uniqueness". The future special education teachers have much more difficulty with fixation and adequate interpretation of significant, typical, and especially barely visible external demonstrations of personal characteristics of the children with special educational needs than preschool teachers. We suppose that it is depend on individual strengths, personality and experiences so particular disabilities will impact differently on individual children, therefore special education teacher have a lot of problems with identifying, diagnosing and treating the condition coupled with the need to find the right kind of support, schooling and development. Besides, some of main social mechanisms of human understanding (such as identification or stereotypization) are not effective in this situation, even more - it is distractive for the process of fixation and interpretation of personal characteristics of the children with special educational needs.

According to the empirical data, the main psychological features of professional observation skills of future special education teachers are domination of professional motives and goals of demonstrating observation skills; they express stable professional interest in fixation and interpretation of external demonstrations of personal characteristics of a child with special educational needs (their parents and teachers in particular). The majority of the students under study are characterized by sufficient indicators of the capacity of perception and perceptivity; concentration, stability and distribution of attention; image and longterm memory; analysis, synthesis, comparison, abstraction, and generalization. These features indicate potential opportunity of observation skills demonstration by future special education teachers. At the same time, they make a lot of mistakes when comparing, differentiating, and explaining personal characteristics of children with special educational needs. It can be negatively impact to the recognizing, accepting and understanding of child's special educational needs.

\section{Types of professional observation skills of future special education teachers}

Having analyzed of psychological peculiarities of demonstration of professional observation skills by future special education teachers, considering the level of development and balance of this quality's structural components, the following types of professional observation 
skills can be distinguished and characterized: perceptive (8.97\%), potential (53.43\%), formal (28.63\%), and deceptive (8.97\%). Each type is represented by its defining characteristics. Let is consider them in details.

The perceptive type is characterized by well-balanced development of the motivational and target-oriented, cognitive and operational components, which are demonstrated in various types of professional activities consistently and at the high level; domination of students' motives and goals; the high level of development of cognitive mental processes that form the basis for this quality. Maturity of the ability to distinguish personality's external demonstrations precisely, establish interrelations between them and interpret them adequately is observed. These special education teachers are able to detect and under-stand significant, typical and barely visible demonstrations of personal characteristics peculiar to the children with special educational needs. They dedicated to giving each individual student the tools and guidance needed to help them maximize success. It becomes the basis for relatively precise prediction of their intents, actions and deeds, development of events, situations, processes and phenomena under real-life conditions. For this reason, this very type of future special education teachers' professional observation skills is the most preferable one for successful, efficient and impactful fulfillment of their professional duties.

The potential type of professional observation skills is observed in case future special education teachers are eager to learn and understand the participants of the educational process for creating and providing favourable conditions for children's harmonious development. It is characterized by sufficient level of development of cognitive processes which are the basis for professional observation skills. That is why future special education teachers want and are able to notice personal characteristics of children with special educational needs (their parents, colleagues), but make mistakes in their interpretation. It is explained by insufficient formation of the ability to detect necessary and sufficient external demonstrations of a personality, their differentiation, comparison and interpretation. In this case, it is possible to change the situation in terms of its harmonization by means of purposeful work on the development of one's own professional observation skills.

The formal type of professional observation skills is characterized by domination of students' cognitive motives and goals of their demonstration in professional activities. Future teachers with this type of 
observation skills invest their efforts not "for the sake of children with special educational needs" (e.g. creating conditions, revealing child's potential and capabilities, etc.), but "for the sake of themselves" ("I wonder why it is happening", "What if..."). In general, the students are characterized by sufficient level of development of cognitive mental processes that form the basis for professional observation skills. However, unreasonable succession of detecting and interpreting personality's external demonstrations is observed, which results in mistakes in understanding one's personal characteristics and special educational needs. It enables future special education teachers to distinguish and analyze significant and typical external demonstrations of the participants of the educational process at school, but makes it difficult for them to notice barely visible changes of their mental state, behavior, etc. In this case, details and nuances are not always interesting for the students, as long as they often attach little importance to them. The most important thing for them is to perform their professional duties at the standard level.

The deceptive type of professional observation skills is characterized by the fact that future special education teachers do not understand the importance and necessity for learning and understanding personal characteristics of children with special educational needs (their parents, colleagues) for performing their professional duties. These students have insufficient level of development of cognitive mental processes which are the basis for professional observation skills; need outside activation and control. Future special education teachers tend to notice only separate, the most noticeable demonstrations of personality's characteristics; analyze, compare and interpret them in quite a superficial manner. The above-mentioned features have negative impact on the organization and providing of educational process, as long as special education teachers with superficial observation skills in most cases neither notice, nor understand even significant and typical external demonstrations of children's personal characteristics and their special educational needs.

These types of professional observation skills of future special education teachers make it possible to understand the existing difficulties and find ways for their purposeful overcoming at the stage of preparation for teacher's work. 


\section{CONCLUSIONS}

Theoretical and experimental study of the issue of professional observation skills of preschool teachers enables us to draw the following conclusions:

- the essence of professional observation skills involves fixation and interpretation of significant, typical and even barely visible external demonstrations of personal characteristics of the participants of the educational process: children with special educational needs, their parents, and colleagues;

- professional observation skills are particularly important in the structure of professionally important qualities of future special education teachers; they are the basis for learning and understanding children with special educational needs, determine success and efficiency of performing a number of professional functions (research, organizational, motivative, prognostic, controlling, regulatory or correctional);

- the main psychological features of professional observation skills of future special education teachers are domination of professional motives and goals of demonstrating observation skills; they express stable professional interest in fixation and interpretation of external demonstrations of personal characteristics of a child with special educational needs (their parents and teachers in particular); future special education teachers have a potential opportunity of observation skills; however, they make a lot of mistakes when comparing, differentiating, and explaining personal characteristics of children with special educational needs:

- the main types of special education teachers' observation skills are perceptive, potential, formal, and deceptive. The most preferable one for successful, efficient and impactful fulfillment of their professional duties is perceptive type of observation skills. But a lot of the students majoring in special education have the potential type of professional observation skills, which indicates the need and opportunity for its purposeful development at the stage of preparing for the future work.

\section{SUMMARY}

The paper presents the results of theoretical and empirical study of future special education teachers' professional observation skills. The latter are considered as the basis for understanding children's personal characteristics and special educational needs, which makes them 
particularly important among the professional qualities of a special education teacher. The following methods were applied: theoretical (analysis, synthesis, generalization of scientific literature); empirical (observation, questioning, testing); statistical (comparative and correlation analysis); interpretative (analysis, synthesis, systematization of the data obtained). Professional observation skills are considered as a professionally important quality, which involves fixation and interpretation of significant, typical and even barely noticeable external demonstrations of educational process participants' personal characteristics. It has the following functions: research, organizational, motivative, prognostic, con-trolling, regulatory or correctional. Professional observation skills are characterized by the following structural components: motivational and target-oriented, cognitive, operational. The data obtained have made it possible to distinguish and characterize the types of future special education teachers' professional observation skills (perceptive, potential, formal, and deceptive). It has been found that most of the students under study have the potential type, which is manifested in their desire and ability to notice personal characteristics of children with special educational needs, their parents and colleagues. However, they make mistakes in interpretation of these demonstrations. These peculiarities indicate the need and opportunity for purposeful development of professional observation skills at the stage of future special education teachers' preparation for future work.

\section{REFERENCES}

1. Ананьев Б. Г. Воспитание наблюдательности школьников. Л. : Лениздат, 1940. 64 с.

2. Басов М. Я. Избранные психологические произведения. М. : Педагогика, 1975. 432 с.

3. Бех І. Д. Виховання особистості : підручник. К. : Либідь, 2008. $848 \mathrm{c}$.

4. Біла I. Спостережливість - ключ до пізнання. Дошкільне виховання. 2008. № 4. С. 9-11.

5. Бодалев А. А. Восприятие и понимание человека человеком : монография. М. : Изд-во Моск. ун-та, 1982. 200 с.

6. Боришевський М. Й. Особистість у вимірах самосвідомості : монографія. К. ; Суми : Еллада, 2012. 608 с. 
7. Занков Л. В. Наглядность и активизация учащихся в обучении. М. : Учпедгиз, 1960. 316 с.

8. Кислова Г. И. Развитие наблюдательности в процессе профессиональной подготовки будущих учителей : дис. ... канд. психол. наук : спец. 19.00.07 «Педагогическая психология». Рос. гос. пед. ун-т им. А. И. Герцена. СПб., 1995. 144 с.

9. Климов Е. А. Введение в психологию труда : учебник. М. : Культура и спорт: Издательское объединение «ЮНИТИ», 1998. $350 \mathrm{c}$.

10. Ковалев В. В. Развитие наблюдательности студентов-психологов в процессе изучения дисциплин анатомо-физиологического цикла : дис. ... канд. психол. наук : спец. 19.00.13 «Психология развития, акмеология». М., 2010.171 с.

11. Колодина Л. В. Наблюдательность личности как фактор формирования педагогического взаимодействия в системе «Учитель-Ученик»: дис. ... канд. психол. наук : спец. 19.00.01 «Общая психология, история психологии». Новосибирск, 2000. $176 \mathrm{c}$.

12. Кузьмина Н. В., Реан А. А. Профессионализм педагогической деятельности : методическое пособие. СПб. : Рыбинск : [Б. и.], 1993.54 с.

13. Лабунская В. А. Экспрессия человека: общение и межличностное познание. Ростов н/Д : Феникс, 1999. 592 с.

14. Мандрыкина Т. С. Формирование педагогической наблюдательности будущего учителя в процессе общения : автореф. дис. на соиск. науч. степени канд. пед. наук : спец. 13.00.01 «Общая педагогика, история педагогики и образования». К., 1987. 20 с.

15. Маркова А. К. Психология труда учителя : кн. для учителя. М. : Просвещение, 1994. 192 с.

16. Морозова Е. В. Психологическое наблюдение как метод человековедческого познания : автореф. дис. на соиск. науч. степени канд. психол. наук : спец. 19.00.01 «Общая психология, психология личности, история психологии». М., 1995. 21 с.

17. Ніколенко Д. О. Психологічні особливості спостережливості в процесі випереджального відображення дійсності. Юридична психологія і педагогіка : наук. журнал. К. : Національна академія внутр. справ, 2014. № 1 (15). С. 21-32. 
18. Психологические основы профессиональной деятельности : хрестоматия / [сост. и общ. ред. В. А. Бодров]. М. : ПЕР СЭ ; М. : Логос, 2007. 854 c.

19. Регуш Л. А. Практикум по наблюдению и наблюдательности. СПб. : ПИТЕР, 2008. 208 с.

20. Савчин М. В. Педагогічна психологія : навчальний посібник. К. : Академвидав, 2007. 422 с.

21. Цибуляк Н. Психологічні особливості прояву спостережливості майбутніх вихователів дошкільних навчальних закладів. Педагогіка і психологія професійної освіти. 2013. № 4. С. 194-202.

22. Knapp M., Hall J. Nonverbal communication in human interaction. N. Y. : Harcone Brace College Publishers, 1997. 482 p.

23. Jablon J. R. , Dombro A. L., Dichtelmiller M. L. The power of observation. Teaching Strategies, 1999. 134 p.

\section{Information about the author:} Tsybuliak N. Yu.

$\mathrm{PhD}$ (Candidate of Psychological Sciences), Associate Professor, Department of Applied Psychology and Speech Therapy

Berdyansk State Pedagogical University 4, Shmidta str., Berdyansk, 71100, Ukraine 